numerous scientific societies and philosophical institutions in all the leading towns.

Were all who in London and the provinces are associated for the promotion of science carefully. calcu lated, we should find that there are now about 120 learned societies, with an aggregate of 60,000 members; and deducting from the number at least one-fourth for members who belong to more than one society, we arrive at the interesting fact that there are, in the United Kingdom, 45,000 men representing the scientific world, or in the proportion of fifteen in every ten thousand of the entire population; the "upper ten thousand" of the aristocracy of learning being thus three times as many as the "upper ten thousand" of the aristocracy of wealth. But are we satisfied with the result? Are all the societies equally active in encouraging the pursuit of science? Are their terms of admission too loose or too narrow? Without entering into the internal management of our learned societies, we might wish for a fuller and earlier publication of their transactions, for the collection of more complete technical libraries, properly catalogued and classified, and for a better action in the way of granting tokens of recognition to successful discoverers and investigators of the great arcana of Nature.

Within the last twenty years, at least half as many new societies have been formed for the promotion of science, and evidences are not wanting to show that an enormous stimulus has been given to science in every direction. In the number of scientific works published, and in the circulation which they have had; in the variety of scientific journals started and successfully maintained; in the respect paid to Science - ay, in the very popularity which greets Science, wherever it exhibits itself, we see abundant reason for congratulation. A brilliant future opens itself for the cultivation of science. Happy will it be when "many shall run to and fro, and knowledge shall be increased;" happy when men will realise that "pleasure is a shadow, wealth is vanity, and power a pageant; but knowledge is ecstatic in enjoyment, perennial in fame, unlimited in space, and infinite in duration." Truly, in the performance of this sacred office the man of science "fears no danger, spares no expense, looks in the volcano, dives into the ocean, perforates the earth, wings his flight into the skies, enriches the globe, explores sea and land, contemplates the distant, examines the minute, comprehends the great, ascends to the sublime, no place too remote for his grasp, no heaven too exalted for his reach."

LEONE LEVI

\section{THE DEPTHS OF THE SEA}

$T \mathrm{HE}$ opening meeting of the Royal Society on Thurs: day last was attended by a numerous assemblage of men of science, especially attracted by the announcement that Dr. Carpenter, representing a committee consisting of Professor Wyville Thomson, Mr. Gwyn Jeffreys, and himself, would communicate the results of the deep-sea dredging explorations, carried out in the course of the past summer and autumn in the Porcupine, a vessel expressly fitted out and placed by the Government at the disposal of the committee for this purpose.

At the conclusion of Dr. Carpenter's lucid exposition, which was necessarily but a mere résumé of the report itself, it appeared quite evident that rumour had not at all exaggerated the scientific value of these explorations, for it is not too much to say that the results of this expedition inust be classed with the most important which of late years have been brought before the notice of the scientific world.

More than a quarter of a century ago, the late Edward Forbes, one of the first naturalists who took the common oyster dredge from the hands of the fisherman to convert it into an instrument for extended scientific research, after employing it in the commencement along the shores of his native little Isle, and subsequently in the seas surrounding the British Islands, and in other parts of Europe, found, upon comparing his observations, that there appeared to be evidence in favour of the existence of a succession of natural zones of marine life according to depth, which zones, however, seemed to become more and more sterile in organisms in descending order; until at last it suggested itself that a zone might be arrived at, at a depth roughly estimated as exceeding 300 fathoms from the surface, containing but sparse traces of organic life, or even such an one as might be entitled to the appellation of Azoic.

This latter hypothesis was brought forward by him as a suggestion worthy of consideration, and not as a dogma or established principle, as he was fully aware that in the dredging explorations which he had been able to carry out up to that time, he had never reached so great a depth as even 300 fathoms, below which the sea-bottom was inferred to be comparatively or altogether sterile; on the contrary, whilst advancing the conclusions which seemed to be but natural deductions from the data then at his disposal, he continually kept pointing out that whether such an hypothesis was correct or not, it was of the highest importance to science to prosecute these researches further, so as to ascertain the true nature of the deep-sea bottom, for, to use his own words in his "History of the European Seas," "it is in its exploration that the finest field for marine discovery still remains."

Before the author of this suggestion had time or opportunity for carrying out such explorations as would have verified or disproved his hypothesis, he was unfortunately cut off by an early death; whilst the hypothesis, in the state in which he had left it, was without further investigation eagerly grasped at and accepted by men of science, both at home and abroad, for the special reason that it appeared to afford a simple explanation of various phenomena which had long remained enigmas to both palæontologists and geologists ; as, for example, amongst others the occurrence, in various periods of the earth's history, of vast accumulations of sedimentary strata apparently altogether devoid of organic remains.

Although this hypothesis, when somewhat modified, may possibly be found to hold good in respect to certain forms and conditions of life, the results of some casts of the dredge made in depths of from 270 to 400 fathoms in Sir James Ross's Antartic Expedition, and subsequently, the deep-sea soundings described by Dr. Wallich as made in 1860 , in the Bulldog, in vastly greater depths, demonstrated quite conclusively that it could no longer be retained as a generalisation.

It now appears strange to look back and observe what very little notice was taken of these new dilta; more especially of the important researches of Dr. Wallich on 
the North Atlantic sea-bed, which for years, if not all but overlooked, certainly do not appear to have received from zoölogists the full credit which they undoubtedly deserved: geologists and palæontologists were evidently loth to abandon an hypothesis which in many respects suited their requirements.

However long truth may remain dormant, it must eventually assert itself in science as in all other matters, and the advancing strides of Biology and Geology soon demanded that such problems should be definitely and conclusively solved, and that the depths of the sea also should be carefully searched for the missing links of evidence requisite to complete their respective chains of reasoning. This was not felt to be the case in England alone; already in Scandinavia we find the savants of Norway and Sweden working with their slender means in the right direction, and assisted by their Governments with a hearty good-will and determination which could not fail to ensure valuable results, such as have already been brought forward by Sars, Nordenschjold, Torrell, and others.

In England, men of science, equally impressed with the importance of this inquiry, wished, with an honourable pride, to see that the country which had so long claimed the empire of the sea, should, in a question of so purely marine investigation, do something worthy of herself; and, being fully alive to the impossibility of doing so without the aid of the Government, applied themselves first to the task of procuring such assistance. Since it is an acknowledged but melancholy fact, that science does not in England either obtain the high position in society, or the influence with the ruling powers of the country which is accorded to it on the Continent in general, it is a subject for congratulation that the urgent appeals made to the Government should have in this instance proved so successful; and after the Government had provided the ships and equipment necessary for the expeditions of last year and this, it is a further subject for congratulation that the direction of these scientific explorations should have been entrusted to such able men as Dr. Carpenter, Prof. Wyville Thomson, and Mr. Gwyn Jeffreys, who constitute the present committee.

The expedition of last year being the first of its kind, had, as might be anticipated, many difficulties to contend with; the ship itself, besides starting at a late season of the year, was ill suited to the undertaking, was provided with but extremely inefficient winding machinery, imperfect appliances and instruments, and moreover, the observers and their assistants had, as it were, to serve an apprenticeship in the management of such operations.

This year, besides being fortunate in securing unusually favourable weather during the major part of the operations, all the above-mentioned difficulties had been provided against; whilst, at the same time, the experience'gained during the last year's cruise contributed very greatly to the complete success of the expedition as a whole.

As yet, it would be premature to attempt any description of the results of these explorations, for the Report which was commer.ced at the meeting of the Royal Society last Thursday is not yet concluded, but is to be continued at its next meeting; sufficient, however, has been already brought forward to prove satisfactorily the great importance of the data obtained to science in general.
Besides corroborating, and in some respects correcting the conclusions deduced from the operations of the last year's expedition, many new facts and observations have been collected, whilst the supply of specimens and materials for examination which have been brought home will no doubt give full occupation to the members of the committee for some time to come, besides obliging them to bring to their assistance the services of the physicist, chemist, and mineralogist, each in their several departments.

The practicability of exploring even the deepest portions of the ocean bed may now be considered to be fully established; the conclusive proofs brought forward showing the existence of warm and cold areas of the deep-sea bottom, in close proximity to one another, each inhabited by its distinct and characteristic fauna, is as surprising as it is important in its scientific bearings, and particularly in its relations to geology and palæontology; whilst the investigations into the temperature of the different ocean zones, and the nature of the gases contained in the seawater at various depths, are intensely interesting and suggestive.

The question as to the existence of an azoic ocean zone at any depth, must now be regarded as finally settled in the negative. The hypothesis which appeared to Edward Forbes to be warranted by all the data which the science of his day could supply, must now be abandoned; it is certain, however, that all who knew him will do his memory the justice of believing that, were he now alive, so far from regretting the necessity of withdrawing a suggestion which appeared to explain several important points in science now once more involved in obscurity, he would have been the first of the converts to the views now proved to be more correct, and the first to congratulate the members of the deep-sea dredging committee upon so successful and brilliant a termination of their labours.

\section{DAVID FORBES}

\section{PHYSTCAL METEOROLOGY}

\section{I.-ITS PRESENT POSITION}

I $T$ is a well-known remark of the historian of science that our progress in astronomy has been made in exact accordance with certain laws which regulate the advancement of knowledge. Neither the march of the sun by day, nor that of the moon by night, is more rigidly surrounded and circumscribed by law than the march of that intellect which has successfully interpreted celestial motions.

We had first of all an observing age. Thousands of years ago in the plains of the East we had astronomers who, albeit with imperfect instruments, lacked neither zeal nor intelligence in their nightly study of the stars. Many of their theoretical ideas were untenable, nay, even absurd, but yet they served to bind together into a formal law the mass of observations which their nightly industry collected.

And so step by step our knowledge of celestial motions progressed, until it culminated in the discoveries of Copernicus and Kepler; and we were presented at last with a bird's-eye view of the solar system, taken, as it were, from without, in which that which appears to be, finally gave place to that which is. Thus the first stage was passed, and astronomers had now another question to put to the universe: it was no longer What are the real motions of 